\title{
THE HISTORICAL FAILURE OF BROTHERHOOD IN MODERNIST INTERCULTURAL REGIMES
}

\author{
ANTHONY PyM*
}

The family is a privileged model for sociological approaches to intercultural regimes. Not only does it have an ethnological basis in certain views of how national relations are built, ${ }^{1}$ but it is also widely used by cultural producers themselves as a source of arguments both for and against the building of international cultural relations.

I propose to indicate why one of these arguments, the claim to international brotherhood, became important and then unimportant in the development of post-Romantic regimes in Europe. I do not propose to address the argument's obvious exclusion of women, which reproduces a wider social exclusion, but shall instead concentrate on the ways in which imaginary cultural brotherhood was used to oppose real or imaginary fathers. I shall finally assess, negatively, the role that arguments based on brotherhood might be expected to play in the future of European internationalism.

\section{NATURAL AND CULTURAL FAMILIES}

The family minimally imposes relations that are vertical or generational (parents to children) and horizontal or fraternal (between siblings). Like the twin axes of Cartesian coordinates, these two directions define a zero-point, the centre of a social place into which the subject is born, without choice, and is stamped with a series of identity-card elements like name, date of birth, class, race, language, religion and of course nationality. This might be described as the natural family in the sense that birth is a fairly natural occurrence, but the extension from natio to nation means that everything else implied in the identity card also appears to be natural or takes on the air of a second nature. When nature was considered to be globally positive, the elements defining the natural family also tended to be accepted as globally positive: moral subjects remained faithful to their identity cards, accepting the natural zero-point as the mark of an inner identity and believing that they should organically create their life and work from there. To refuse that identity, to stray from the fold in search of external influences, was thus to risk decadence and betrayal of the true self. But post-Romantic aesthetics were marked by incipient class agitation and scientific doubts about the global worth of nature, and thus doubts about which side of national and class frontiers decadence was really to be found. 'C'est la nature qui pousse l'homme à tuer son semblable...' claimed Baudelaire as he justified the cultural second nature of women's cosmetics; 'Toi, libre!' exclaimed Flaubert in

*Departmento de Filologia Moderna, Universidad de Las Palmas, Pérez del Toro, 1, 35003, Las Palmas de Gran Canaria, Spain. 
an early novel, 'dès ta naissance tu es soumis à toutes les infirmités paternelles ...' . ${ }^{3}$ From both the Aestheticist and Naturalist positions-and well before Freud - the uncertain status of nature threatened the wholesomeness of the natural family and all it implied.

Yet families can also be imagined, invented or projected. Cultural producers often seek to define non-biological parents and siblings, usually sought and fixed during initiation into one of the major elements considered non-natural or at least only vaguely prefigured at birth, the subject's vocation or trade. Thus are formed peculiarly cultural families, distinct from natural families and yet related to society with the same relative autonomy as the resulting cultural forms. Of the many historical structures these secondary families may adopt, the prime model is that of artisanal apprenticeship, based on learning from and replacing a master. In the individual case this is a conflictual vertical relationship, perhaps always of the kind Harold Bloom claims is general for relations between great poets: 'The history of poetry is an endless civil war, indeed a family feud'. ${ }^{4} \mathrm{Or}$ again, according to Barbara Johnson, 'Ecrire, pour Mallarmé c'etait toujours tuer Hugo'. ${ }^{5}$ However, the facile homology assumed by such readings-that cultural families reproduce the natural family-also assumes a closed social space that is not always historically valid: Bloom's titanic poets fight on an imposed battlefield restricted to the English language and mostly to London, as if there were no other poets in Europe; Mallarmé apparently encountered Hugo in the enclosed ring of literary Paris, as if he had no concerns beyond the political present or no knowledge of English or German culture. I believe that this enclosed space characterises peculiarly Romantic encounters, not only vertically but also in the horizontal relationships involved in such struggles: the Romantic notions of the School and the Generation imply descent from a Master or a Progenitor, present in body or spirit to keep the children in place. But what happens when the natural family is not automatically good and the home is troubled by drives to go beyond its enclosed space? What is expressed, for example, in the numerous foreign and exoticised pseudonyms that abound amongst French and Hispanic writers of post-Romantic generations? When Mallarmé exoticised 'Etienne' or as a schoolboy took to calling himself the 'Marquis de Boulainvilliers', ${ }^{6}$ the passage to culture was expressed in transformation of the natural family. Writing, for Mallarmé, perhaps first meant sublimating his natural father.

If the relations of production typical of national cultures may be defined in terms of a high degree of non-transformational correlation between natural and cultural identity cards, international cultural relations might then be based on transformations or low degrees of correlation. But the problem does not lie here-the definition can locate fairly well the twin tendencies of national and international cultures that went right through to the end of the nineteenth century-; the problem is rather to explain how the transformations or low degrees of correlation historically came about.

The most obvious explanation lies in purely material factors like travel, translations and chance; in short, the development of international trade and communication systems placing different cultures increasingly in contact. But contact is not in itself an influence. The presence of foreign elements must have some effect on existing national structures before it can lead to anything 
substantially international. And if existing family structures are weak because nature is no longer good or class society has become mobile, such effects are likely to be far-reaching, revealing the inadequacy of presumed critical homologies between natural and cultural families.

\section{BROKEN HOMES}

The coordinates of all families may be broken in order to produce two derivative models, both based on isolation of the subject. First, negation of the vertical relation gives the figure of the orphan, with companions of the same generation but a broken link to the preceding generation. Second, and no less important, denial of horizontal relations defines the figure of the only child, hemmed into relations of dependence and conflict with the preceding generation. When these derivatives occur on the cultural level, they may lead to further projections of lost fathers or lost brothers, of a lost tradition or a lost generation. In this way the model of the family can itself produce a drive away from an enclosed national space, leading to imaginary cross-cultural relations, reinventing further families as defences against accusations of illegitimate influence, plagiarism or betrayal of the inner self.

Notions of the broken home may also be found in drives to maintain the closed space of national cultures. For Gabriel Tarde, for example, all foreign art was 'immoral et dissolvant, parce qu'il apporte avec lui-même son .but, l'aspiration spéciale, collective et patriotique du lieu de naissance'. ${ }^{7}$ That is, foreign elements are all well and good, but only in their own place; they should not be allowed to break away from their original locus. Extension of this apparently universal principle also allows Tarde to tell when a work of art is foreign: 'Quand l'art se présente séparé de la morale, quand il est un agent non d'harmonie, mais de dissolution sociale, c'est un signe qu'il est importé du dehors' ${ }^{8}$ Faced with principles like this, one might expect some outcry on behalf of international culture.

\section{THE PASSIVITY OF BROTHERHOOD}

Post-Romantic brotherhood comes into play as an imaginary relation produced by cultural orphans and only children, mostly from the position of outcast, isolated or maudit artists. Whereas the School might have followed a master into attack, proclaiming its principles as eternal truth and denouncing immediate predecessors or mortals of lesser worth, brotherhood relations were mostly defensive, passive and devoid of immediate master figures. Thus, as the most obvious example, the term 'Pre-Raphaelite Brotherhood', although certainly reacting against established British aesthetics, does not name any particular master but rather seeks to jump over generational sequences and geographical boundaries in search of a lost and foreign tradition. The reference to brotherhood was in this case certainly motivated by use of the term in other kinds of secondary and equally international families, notably in the church and in trades unions, both as traditional guilds and as the incipient international 
organisation of working class interests. The various registers of the term all invoke inclusion and exclusion on the basis of solely vocational criteria, thus allowing for foreign elements in their membership cards (the Rossettis) and low degrees of correspondence with national cultures (their work was attacked as being non-English). In the sense that it cuts across boundaries, the ideal of brotherhood might be associated with the later critical conceptions of artistic 'movements' and a generalised avant-garde, described by Poggioli in terms of its penchant for making enemies. ${ }^{9}$ But post-Romantic brotherhoods do not seem to have openly attacked anyone. The Pre-Raphaelites, to continue the example, were defended from beyond, by a non-member named Ruskin. Mallarmé never explicitly criticised Hugo. The ideal of brotherhood is remarkably inward looking and would correspond more to the numerous 'circles' that developed in eastern Europe towards the end of the century. Far from being organised pseudomilitary units, cultural fraternities would instead appear to have remained enshrouded in mystery, both within and without. Their battles were secret, psychological affairs. Indeed, organised around the absence of a master and from the passive position of lost children, few save their opponents could be really sure of their existence.

Great care should thus be taken with the historical reconstruction of supposedly victorious international movements. What is now called Symbolism, to take a prime example, was certainly based on a geographically centred internationality-as Anna Balakian puts it, 'Symbolism was not French; it happened in Paris ${ }^{10}$ - but the absence of any recognised master makes it very difficult to place in the history of ideas. Mallarmé certainly never referred to Moréas' banner in any unambiguously positive sense, and he himself remained an entirely obscure figure until portrayed in a decadent context by the Naturalists Huysmans and Huret. As for Verlaine, similarly occasionally hailed as master, his appearance in Huret's Enquête has him disclaim any connection with this decidedly foreign invention: 'Le Symbolisme?... Ça doit être un mot allemand"! " And in a sense it was indeed a German term, for it was not until Max Nordau's 1892-93 Entartung put the figures of Mallarmé, Verlaine and the rest in their international context that separated points of this supposed movement had a reasonably coherent image of the whole. Prior to that date, prior to Nordau's positivist naming of Aestheticism as decadence, the notion of brotherhood remained remarkably non-antagonistic and uncentred, almost totally devoid of any well-defined milieu d'artiste. Similarly, the London of the 1890s saw numerous non-English writers and artists produce within the context of an international culture, but it would be difficult to define their attitudes as either collective or oppositional. Isolated red jackets and green carnations may have been taken as non-nationalistic, but they themselves did little more than advertise lost individuals in search of each other or a sartorial tradition.

The unity of these literary movements was only seen after their ending, in England after the trial of Oscar Wilde-the fall he actively sought as an individual-and the Boer War, and in France during the Dreyfus Affair and the 1898 'Manifeste des Intellectuels', when the French became aware of the nonFrench origins of writers like Moréas, Verhaeren, Maeterlinck, Vielé-Griffin and Merrill, when Boschot set about founding the Ecole française, ${ }^{12}$ and when Bertrand joined anti-Semitism with mistrust of the influence of "barbares 
Anglo-germains' to insist that French artists come from 'l'aristocratie naturelle du pays' ${ }^{13}$ Prior to these reactions, there was little but imagination to react against.

\section{BAUDELAIRE AND HIS BROTHERS}

The essentially passive and secretive nature of brotherhood may be appreciated through brief consideration of one of its better-known manifestations, the international influence of Baudelaire, of Les Fleurs du mal as what Benjamin considered the last poetic work to have European influence,,${ }^{14}$ and specifically of the poet's status as what one translator has termed 'a man amongst men, the fraternal Baudelaire, he who will always be our brother'. ${ }^{15}$

Fraternity here is obviously motivated by Baudelaire's address to a 'hypocrite lecteur, mon semblable, mon frère'. But at the time of Baudelaire's writing, who or where was this brother, this second person at once reader (lecteur) and perhaps writer (mon semblable)?

The historical appearance of Les fleurs du mal was meaningful in opposition to the comfort of family life ('la douceur du foyer') ${ }^{16}$ beyond the enclosed space of the natural family. It was an attempt to communicate with a cultural family of urban outcasts, a fraternity of real or potential poets. But in 1857 Le Figaro described Baudelaire as 'un poète immense pour un petit cercle d'individus', and he was to remain the little-known poet of isolated individuals right through to at least 1884, when Huysmans and others resurrected him as a lost father. In terms of avant-garde aesthetics, this second-person reader, this mirror-image of the poet, should perhaps then be the reader in an enlightened future. But in terms of brotherhood, on the model of Pre-Raphaelite belatedness, it may even be a poet from the past.

Baudelaire talks about resemblance in a different but perhaps not unrelated context: 'Et bien! On m'accuse, moi d'imiter Edgar Poe! Savez-vous pourquoi j'ai si patiemment traduit Poe? Parce qu'il me ressemblait'. ${ }^{17}$ Metaphor of a purely visual similitude, this resemblance suppresses all distance except temporal anteriority: 'La première fois que j'ai ouvert un livre de lui, j'ai vu avec épouvante et ravissement, non seulement des sujets rêvés par moi, mais des phrases pensées par moi, et écrites par lui vingt ans auparavant'. ${ }^{18}$ Through a kind of metempsychosis-curiously repeated in Dorian Gray's reading of $A$ reboursPoe thus enters the restricted circle of the poet's immediate family: 'Je veux faire tous les matins ma prière à Dieu, et à mon père, à Mariette et à Poe commes ses intercesseurs'. ${ }^{19}$ The American has thus become an imaginary brother. No one can now criticise Baudelaire for having imitated a foreigner; no one can now accuse him of having betrayed his inner identity or natural family... simply because the foreigner has been integrated, defensively, into the poet's cultural family. And if brotherhood can thus precede and justify a moment of intercultural creation, why should it not follow it in the search for further secondperson resemblances over the horizon or in the future?

The 1,300 copies of the first edition of Les Fleurs du mal sold well, no doubt because they were the object of a court trial, but the trial was lost, distribution was interrupted and the work gained all the value of a rare jewel reserved for only 
a few privileged readers. In England Swinburne had not seen a copy of the first edition and borrowed Rossetti's. ${ }^{20}$ Some thirty years later the Australian poet Brennan found no copy of any edition at all in the public libraries and borrowed one from a poet friend. ${ }^{21}$ Baudelaire thus crossed the globe as a little-known book to be passed hand to hand, from poet to poet. Thus was formed a small network of imaginary brothers, not without its echoes of requited fraternity. Swinburne, who had declared Hugo an authoritarian father ('Thou art chief amongst us, and lord'), ${ }^{22}$ reserved quite a different greeting for Baudelaire: 'Thou sawest, in thine old singing season, brother, /Secrets and sorrows unbeheld by us' ${ }^{23}$ And as for the suggested metempsychosis with Poe, later taken up by Wilde, in 1883 the Belgian writer Albert Giraud depicted a young writer struggling with its imaginary extension: 'C'était come si, par quelque sort étrange venu d'outretombe, Baudelaire guidait la main de Jean lorsqu'ilécrivait. Non, il n'était pas un plagiaire, c'est Baudelaire qui lui volait son âme'. ${ }^{24}$

It is in this atmosphere of brotherhood as a secret pact or conspiracy that Baudelaire, with Poe, came to symbolise an entire world of solitary writers, alone with their night, their books and the inspiration they hoped to find from distant relations. Hence, lamentably and as a final echo selected from an extremely long list, Herrera y Reissig's decadent verses of 1900:

\footnotetext{
Soy la silenciaria, la de negras alas, la trasnochadora que las almas roe, la que tiene brillo de las luces malas en que se inspiraron Baudelaire y Poe. ${ }^{25}$
}

The fact that rhyme requires Edgar Allan Poe to be pronounced 'Poé'-perhaps after the fantasied French transcription 'Poë'-suggests that the atmosphere of international brotherhood was more important that any direct knowledge or understanding of foreign brothers. An influential Spanish-American literary history written at the turn of the century repeats the association of Baudelaire with a dangerous decadent tradition, but erroneously dates his influence from the $1830 \mathrm{~s}^{26}$ Swinburne no doubt knew better, but one wonders if he really cared: after all, he also hailed imaginary brothers in review articles on a nonexistent French poet and critic. ${ }^{27}$ But this relative ignorance or indifference was already implicit in Baudelaire's recreation of Poe: 'Il faut, c'est-à-dire je désire, qu'Edgar Poe, qui n'est pas grand chose en Amérique, devienne un grand homme pour la France' ${ }^{28}$ In the final analysis, foreign brothers tended to be created for home consumption.

It would be wrong to describe such relations between cultural producers in terms of international movements or as an immediately international culture. Cultural brotherhood, in the sense implied in the Baudelaire-Poe example, is rather a product of transformed family models within the receiving cultures, since in each case there is a felt need to escape from isolation or a lack of immediate tradition. It is then in this lack of a profound appreciation of otherness, and not particularly in any reactionary return to nationalist cultures, that the historical failure of brotherhood is to be explained. 


\section{THE FUTURE OF BROTHERHOOD}

It is not surprising to see that the commercial development of internationalism, in favouring relations between products-styles or trends-rather than producers, has worked against fraternal relationships. The ideal of brotherhood, originally based on passive outcast positions and mostly undeveloped into any profound understanding of otherness, expressed discontent with given situations and only rarely led to the creation of substantially new situations. As such, it has only survived in the form of specific sub-cultures where the death of the artist has not been denied and where, notably from feminist and homosexual positions, paternalistic relationships are more actively opposed than was the case in properly Modernist regimes.

Universidad de Las Palmas

Anthony Pym

\section{NOTES}

1. For E.B. Tyler, for example, 'exogamy cements uncultured populations into nations capable of living together in peace'. In 'On a Method of Investigating the Development of Institutions, Applied to Laws of Marriage and Descent', Journal of the Royal Anthropological Institute, 18 (1888), p. 267.

2. Charles Baudelaire, 'L'Art Romantique. Le peintre de la vie moderne', in OEuvres complètes (Paris: Club français du livre, 1966), p. 286.

3. Gustave Flaubert, Mémoires d'un fou [1838], in OEuvres de jeunesse inédites I, (Paris: Armand Colin, 1910), p. 244.

4. Harold Bloom, Kabbalah and Criticism (New York: Continuum, 1975), p. 63; The Anxiety of Influence: A Theory of Poetry (New York: OUP, 1973).

5. Barbara Johnson, Défigurations du langage poétique (Paris: Flammarion, 1979), p. 172.

6. Henri de Régnier, Nos Rencontres (Paris: Mercure de France, 1931), p. 191.

7. Gabriel Tarde, La logique sociale (Paris: F. Alcan, 1895), p. 396.

8. Ibid.

9. Renato Poggioli, The Theory of the Avant-Garde [1962] (New York: Harper \& Row, 1968), p. $25 \mathrm{ff}$.

10. Anna Balakian The Symbolist Movement (New York: Random House, 1967), p. 5.

11. Paul Verlaine in Jules Huret, Enquête sur l'évolution littéraire [1891] (Vanves: Thot, 1982), p. 82.

12. Cf. Michel Décaudin, La Crise des valeurs symbolistes [1960] (Geneva-Paris: Slatkine, 1981), pp. 99-121.

13. Ibid., p. 139.

14. 'Depuis Baudelaire, la poésie lyrique n'a plus connu aucun succès de masse $[\ldots]$ Les Fleurs du mal sont la dernière œuvre lyrique qui ait exercé une influence européenne'. Walter Benjamin, 'Sur quelques thèmes baudelairiens' [1939] in Littérature et société (Université libre de Bruxelles, 1967), pp. 245, 287.

15. N. Lamarque, 'Discurso apologético sobre Baudelaire' [1956], introduction to Charles Baudelaire Obras (Madrid: Aguilar, 1961), p. 93.

16. Cf. Hans Robert Jauss, 'La douceur du foyer: Lyrik des Jahres 1857 als Muster der

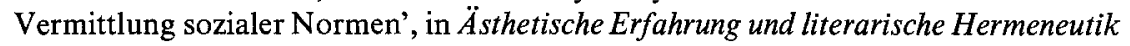


$I$ (Munich: Fink, 1977).

17. Letter to Théophile Thoré, ca 20 June 1864, OEuvres complètes, II, p. 1260.

18. Ibid.

19. Mon coeur mis à nu (Paris: Charpentier, 1965).

20. Enid Starkie, From Gautier to Eliot, The Influence of France on English Literature, 1851-1939 (London: Hutchinson, 1960), p. 42.

21. Wallace Kirsop, 'Notes on Brennan's Reading of Baudelaire', Australian Journal of French Studies, VI (1969), pp. 2-3.

22. Swinburne, 'To Victor Hugo', in Poems and Ballads (First Series, 1866).

23. Swinburne, 'Ave Atque Vale', in Poems and Ballads (Second Series, 1878).

24. Albert Giraud, Le Scribe (Bruxelles: Hochsteyn, 1883).

25. Julio Herrera y Reissig, 'El canto de las horas' in Las Pascuas del tiempo [1900], Poesías completas (Buenos-Aires: Losada, 1942), p. 52. 'I am the silent black-winged woman, the sleepwalking gnawer of souls, she who has the shine of the unhealthy lights which inspired Baudelaire and Poe'.

26. 'Baudelaire es toda la Francia de 1830', Víctor Pérez Petit in Los Modernistas [1903] (Montevideo: Artigas, 1965), vol. I, p. 30.

27. Enid Starkie, ibid.

28. Letter to Sainte-Beuve, 19 March 1856, ibid., II, p. 1230. 